\title{
Attachment mechanism in a highly specific association between ectosymbiotic bacteria and marine nematodes
}

\author{
Andrea D. Nussbaumer ${ }^{1, *}$, Monika Bright ${ }^{1}$, Christian Baranyi ${ }^{2}$, Christian J. Beisser ${ }^{3}$, \\ Jörg A. Ott ${ }^{1}$
}

\begin{abstract}
${ }^{1}$ Section of Marine Biology, Institute of Ecology and Conservation Biology, ${ }^{2}$ Section of Limnology, Institute of Ecology and Conservation Biology, and ${ }^{3}$ Section of Comparative Anatomy and Morphology, Institute of Zoology, University of Vienna, Althanstrasse 14, 1090 Vienna, Austria
\end{abstract}

\begin{abstract}
The marine Stilbonematinae (Nematoda) are known for their highly specific mutualistic association with thiotrophic ectosymbiotic bacteria. The mechanism mediating recognition and binding between symbionts and host was studied in 5 host species. When incubated with D-mannose and L-rhamnose the symbionts detached in 2 species, Laxus cosmopolitus and L. oneistus, most likely due to competitive interactions with sugars involved in the binding mechanism; 3 other species, Stilbonema maium, Eubostrichus topiarius and E. dianae, did not lose their bacteria during any tested sugar incubations. Incubations with lectins binding specifically to D-glucose/D-mannose (ConA, concanavalin agglutinin) and to D-mannose (NPA, Narcissus pseudonarcissus agglutinin) respectively, both in vivo and on ultrathin sections, confirmed that accessible D-mannose is located on the symbionts of $L$. cosmopolitus, but not on the host's surface. Our results showed an involvement of D-mannose and L-rhamnose residues of the bacterial surface in the attachment mechanism. We hypothesize that the recognition and binding of the environmentally transmitted symbionts in the 2 Laxus species, which harbor only 1 phylotype of symbiotic $\gamma$-proteobacterium each, is most probably mediated through a yet unknown mannose/rhamnose-specific lectin of host origin.
\end{abstract}

KEY WORDS: Stilbonematinae $\cdot$ Nematoda $\cdot$ Thiotrophic ectosymbionts $\cdot$ Symbiosis $\cdot$ Environmental transmission $\cdot$ Attachment $\cdot$ Recognition

Resale or republication not permitted without written consent of the publisher

\section{INTRODUCTION}

Several ectosymbioses of marine protists and invertebrates with chemolithoautotrophic sulfur-oxidizing (thiotrophic) bacteria have been described so far. Representatives are Kentrophoros spp. (Karyorelictea, Ciliophora; Fenchel \& Finley 1989), Zoothamnium niveum (Oligohymenophora, Ciliophora; Bauer-Nebelsick et al. 1996a,b, Ott et al. 1998), Stilbonematinae (Desmodoridae, Nematoda; Ott \& Novak 1989, Ott et al. 1991), Alvinella pompejana (Alvinellidae, Polychaeta; Cary \& Stein 1998), Halicryptus spinulosus (Priapulida; Oeschger \& Schmaljohann 1988) and Rimicaris exoculata (Bresiliidae, Crustacea; Polz \& Cavanaugh 1995). Except for Z. niveum, none of the thiotrophic ectosymbioses could be cultivated so far. Moreover, aposymbiotic cultivation of either partner has not been achieved up to now.

All representatives of the marine free-living Stilbonematinae form specific associations with their ectosymbionts, displaying characteristic adhesion patterns (Polz et al. 1992, 2000, Ott 1996). Typically, a microbial consortium is present with the dominance of 1 symbiotic morphotype, as in representatives of Stilbonema. For some species, like Eubostrichus dianae, it has been proven that several phylotypes are consistently present on the host surface (Polz et al. 1999). In Laxus spp., only 1 morphotype was found (Polz et al. 1992), which proved to be a single phylotype of $\gamma$-proteobacterium (Polz et al. 1994). The associations were stable over 
time despite 4 successive molts, during which the bacteria are shed with the old exuvia. Furthermore, as no vertical transmission of symbionts from one to the next host generation has been observed, the uptake is environmental. The specific and consistent adhesion pattern and the stable association over time requires a precise recognition mechanism for the acquisition and maintenance of the symbionts.

In their natural environment almost all bacteria produce an extracellular matrix (ECM) consisting of tangled sugar fibers, which act as the functional surface of the microbe itself (Sutherland 1977, Costerton et al. 1978). The surface coat (SC) of nematodes is described as a mucopolysaccharide-rich layer with occasionally occurring glycoproteins (Zuckerman et al. 1979, Spiegel et al. 1982, Bird \& Zuckerman 1989, Page et al. 1992). Hirabayashi et al. (1992) found the first invertebrate galectin ( $\beta$-galactoside-binding lectin) in the cuticle of Caenorhabditis elegans. The ECM and the $\mathrm{SC}$, respectively, represent a primary mechanism by which microbial cells and nematodes communicate with their environment (Decho 1990, Brandley 1991, Sharon \& Lis 1993). However, very little is known about the particular function of the nematode's SC, although for the parasitic species mediation of host contact and immune evasion was suggested (Bird et al. 1989, Blaxter et al. 1992, Maizels 1993).

In contrast, the chemistry and function of bacterial ECM (synonyms: glycocalix, capsule, slime) is much better understood, especially in pathogens. Carbohydrates have an immense potential for diversity compared with linear nucleic acids and proteins. Recognition of oligosaccharides within the ECM forms the basis of many important examples of viral and bacterial attachment to host cells in the course of infections. The information carried in the ECM is decoded by lectins (Arason 1996). Such carbohydrate-lectin interactions have been described for pathogens (Venkataraman et al. 1997, Ewart et al. 1999, Wang \& Leung 2000, Zamze et al. 2002). For symbiotic bacteria, similar mechanisms have been proposed. In some representatives of the Rhizobium-legume symbiosis, hostspecificity is mediated via lectins interacting with exopolysaccharide components of the rhizobial cell surface (Kijne et al. 1988, Diaz et al. 1995, van Rhijn et al. 1998, Hirsch 1999, Price 1999, Fraysse et al. 2003). For the Vibrio-squid symbiosis, a lectin-carbohydrate-based recognition/acquisition mechanism has been suggested (McFall-Ngai 1994, McFall-Ngai \& Ruby 2000, Nyholm et al. 2002).

The observed high specificity of Stilbonematinae/ bacteria associations render unspecific adherence mechanisms such as net surface charge, hydrophobic or lipophilic forces (Beuth \& Uhlenbruck 1995) unlikely and suggest a carbohydrate-lectin interaction.
We hypothesize that incubation in monosaccharide solutions result in detachment of the symbionts due to saturation of lectin carbohydrate recognition domains. Ewart et al. (1999) demonstrated effective displacement of lectins bound to the surfaces of Aeromonas salmonicida and Vibrio anguillarum by incubation with mannose solutions and suggested that these results point to a lectin binding to mannose on the bacterial surface.

We used representatives of the 3 basic types of epigrowth: a multilayer of cocci (as in Stilbonema maium), a monolayer of rods (in Laxus cosmopolitus and $L$. oneistus) and a coat of non-septate filaments (in Eubostrichus topiarius and E. dianae).

The presence of carbohydrates on the surfaces of the worms and/or the bacteria was investigated by fluorescein isothiocyanate (FITC)-labeled lectins using in vivo incubations; their precise location was determined by in vitro incubations on ultrathin sections with goldconjugated lectins.

\section{MATERIALS AND METHODS}

Worm collection. Stilbonema maium, Laxus oneistus and Eubostrichus dianae were collected in $0.5 \mathrm{~m}$ depth from a back-reef sandbar at Carrie Bow Cay, Belize Barrier Reef (Caribbean Sea; Ott \& Novak 1989); L. cosmopolitus and E. topiarius were collected in $3 \mathrm{~m}$ depth from calcareous sand in Vestar Bay, Rovinj, Croatia (Mediterranean Sea; Ott \& Novak 1989). Sand from each area was transported to Vienna, and kept in buckets at 25 and 15 to $25^{\circ} \mathrm{C}$, respectively. The worms were extracted by gently shaking $200 \mathrm{ml}$ portions of sediment in artificial seawater (35) and pouring the supernatant through a $63 \mu \mathrm{m}$ mesh screen; they were then picked by hand under a dissecting microscope. Only freshly extracted individuals were used for the experiments.

In vivo sugar incubations. Specimens of the 5 different species were incubated in $0.2 \mu \mathrm{m}$-filtered artificial seawater (35) with 10 different monosaccharides, respectively, at various concentrations for $90 \mathrm{~h}$ at room temperature (Table 1). We transferred 2 to 11 replicates, consisting of a minimum of 2 to a maximum of 44 worms of the same species, into glass staining blocks completely filled with approx. $2 \mathrm{ml}$ sugar solution and covered these with glass lids to keep salinity constant $( \pm 1)$. During the whole incubation time, the staining block was shaken gently on a rocking table. A control incubation in artificial seawater without added sugar was carried out alongside each incubation.

The condition of the worms as well as the bacterial coverage were checked under a Nikon SMZ-U stereomicroscope at $100 \times$ magnification approximately every 
Table 1. Laxus cosmopolitus, L. oneistus, Eubostrichus topiarius, E. dianae and Stilbonema maium. Survival rate (percentage of total incubated individuals of each species per treatment) after incubation in different monosaccharide solutions and in artificial seawater (Control) for $90 \mathrm{~h}$. N-acetyl-gal: N-acetyl-galactosamine, N-acetyl-glu: N-acetyl-glucosamine, -: not tested

\begin{tabular}{|c|c|c|c|c|c|c|}
\hline Treatment & Conc. $\left(\mathrm{mol} \mathrm{l}^{-1}\right)$ & L. cosmopolitus & L. oneistus & E. topiarius & E. dianae & S. maium \\
\hline Control & - & 96.2 & 100 & 100 & 100 & 42.4 \\
\hline $\mathrm{D}(+)$-mannose & 0.1 & 100 & 100 & 66.6 & 100 & 0 \\
\hline $\mathrm{D}(+)$-mannose & 0.3 & 84.6 & 72 & - & - & - \\
\hline $\mathrm{D}(+)$-mannose & 0.5 & 81.8 & 78.9 & 75 & 100 & 0 \\
\hline $\mathrm{D}(+)$-mannose & 0.7 & 50 & 40 & - & - & - \\
\hline L-rhamnose & 0.1 & 85.7 & 87.5 & 100 & 80 & 0 \\
\hline L-rhamnose & 0.5 & 80 & 81.8 & - & - & - \\
\hline $\mathrm{D}(-)$-fucose & 0.1 & 91.6 & 75 & 100 & 75 & 100 \\
\hline $\mathrm{D}(-)$-fucose & 0.5 & 92.3 & - & - & - & - \\
\hline $\mathrm{D}(+)$-galactose & 0.1 & 100 & 100 & 100 & 66.6 & 44.4 \\
\hline $\mathrm{D}(+)$-glucose & 0.1 & 100 & 100 & 100 & 66.6 & 42.9 \\
\hline N-acetyl-gal & 0.1 & 42.9 & 55 & 50 & 71.4 & 89.5 \\
\hline N-acetyl-gal & 0.5 & 30 & 50 & - & - & - \\
\hline N-acetyl-glu & 0.1 & 16.7 & 62.5 & 40 & 60 & 9.1 \\
\hline N-acetyl-glu & 0.5 & 20 & 40 & - & - & - \\
\hline
\end{tabular}

$12 \mathrm{~h}$. At the same time, the salinity of each solution was measured. Bacterial detachment was scored only for live individuals.

To ensure that the detachment of the symbionts was not due to osmotic stress leading to disintegration of the bacterial membrane, we measured the osmolarity of the control and the sugar solutions with a $3 \mathrm{MO}$ PLUS Advanced ${ }^{\mathrm{TM}}$ freezing-point osmometer. The osmolarity of the respective sugar solutions differed only slightly from $1074 \mathrm{mOsmol}$ in the $0.1 \mathrm{M}$ to 1098 mOsmol in the $0.7 \mathrm{M}$ solutions. The mean osmolarity of the artificial seawater (control) was 1081 mOsmol. Additionally, we examined the integrity of the bacterial membrane with the LIVE/DEAD ${ }^{\circledR}$ BacLight ${ }^{\mathrm{TM}}$ viability kit (Molecular Probes). After each treatment, we incubated the worms with attached bacteria and the filtered detached bacteria in a component $A: B$ ratio of 1:3, diluted 100-fold, for $15 \mathrm{~min}$ in the dark and viewed them on a Reichert Polyvar I epifluorescence microscope. As it is known that the LIVE/DEAD ${ }^{\circledR}$ kit does not work reliably for all bacterial species, we tested the assay beforehand. Dead and live symbionts were well discriminated by their different color - green for living and red for dead bacteria - and the best results were obtained with the above concentrations.

In vivo incubation with FITC-labeled lectins. Laxus cosmopolitus specimens with attached symbionts were incubated in $0.15 \mathrm{M}$ phosphate buffered saline (PBS), $\mathrm{pH} 7.2$, containing the following FITC-labeled lectins each: concanavalin agglutinin (ConA), specificity $=\alpha-$ D-mannose/ $\alpha$-D-glucose; peanut agglutinin (PNA), specificity $=\alpha$-D-galactose; soybean agglutinin (SBA), specificity $=\mathrm{N}$-acetyl-D-galactosamine, wheat germ agglutinin (WGA), specificity = N-acetyl-D-glucosamine (SIGMA). The worms were rinsed 3 times for
5 min in $0.15 \mathrm{M}$ PBS, $\mathrm{pH} 7.2$, incubated in the same buffer containing $100 \mu \mathrm{g} \mathrm{ml}^{-1}$ lectins in the dark for $30 \mathrm{~min}$, rinsed again in $0.15 \mathrm{M}$ PBS $3 \times 5 \mathrm{~min}$, and observed immediately on a Reichert Polyvar I epifluorescence microscope and photographed.

Post-embedding lectin ultracytochemistry. Several Laxus cosmopolitus specimens were fixed in $4 \%$ paraformaldehyde in 0.15 M PBS, pH 7.2, for several hours, dehydrated in a series of ethanol, and embedded in unicryl ${ }^{\mathrm{TM}}$ (British BioCell International). Ultrathin sections were made with a Reichert Ultracut $\mathrm{S}$ and mounted on Formvar-coated nickel grids. Due to the use of a hydrophilic resin, no etching procedure was necessary prior to lectin incubation (Roth 1978, Herken \& Manshausen 1998).

Narcissus pseudonarcissus agglutinin (NPA) is specific for alpha-linked mannose (terminal and internal residues) and prefers polymannose structures containing $\alpha-1,6$ linkages (Kaku et al. 1990). The biotinylated NPA (Vector Laboratories, Burlingame, California) was diluted to $20 \mathrm{\mu g} \mathrm{ml}^{-1}$ in $10 \mathrm{mM}$ HEPES buffer, $\mathrm{pH} 7.5$, containing $0.15 \mathrm{M} \mathrm{NaCl}$, and $0.08 \%$ sodium azide. Gold-conjugated streptavidin (EM grade $5 \mathrm{~nm}$, Zymed Laboratories, San Francisco) provided in $20 \mathrm{mM}$ Tris, $\mathrm{pH} 8.2,225 \mathrm{mM} \mathrm{NaCl}$ containing $1 \%$ bovine serum albumin, 100-fold diluted in $50 \mathrm{mM}$ Tris buffer, was used as an electron-dense marker. For better localization on the ultrathin sections, the gold particles were enhanced with silver (silver enhancement kit, British BioCell International).

Labeling with the lectin conjugates was performed as a 2-step technique. The grids were incubated in bovine serum albumin (BSA $1 \%$ in 50 mM Tris, pH 7.4) for $20 \mathrm{~min}$ to prevent unspecific binding. Thereafter, they were placed on a $100 \mu \mathrm{l}$ drop of the NPA solution 


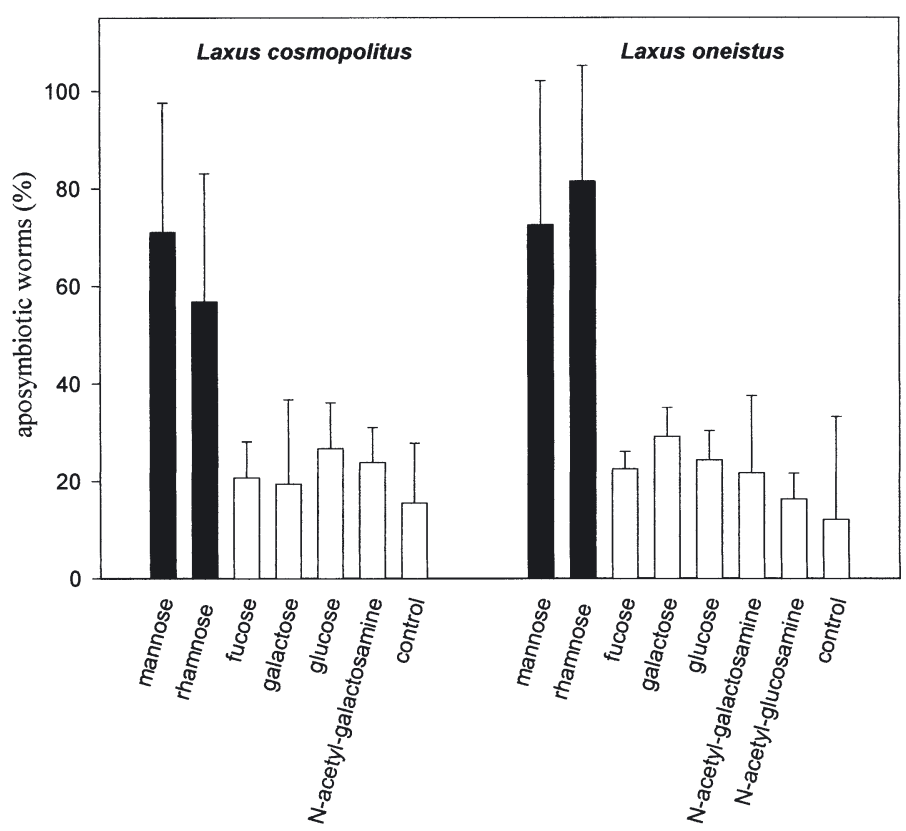

Fig. 1. Laxus cosmopolitus and L. oneistus. Detachment of symbionts after $90 \mathrm{~h}$ incubation determined as mean (+SD) percentage of living, aposymbiotic (bacteria-free) worms after incubation with different sugars and control incubations in artificial seawater. D-mannose and the L-rhamnose treatments differed significantly from all other treatments and from the control. No significant differences were found between D-mannose and L-rhamnose treatments for either species (see p-values in Table 2)

and incubated in a humidity chamber at room temperature for $60 \mathrm{~min}$. After 5 washing steps with $50 \mathrm{mM}$ Tris, $\mathrm{pH} 7.4$, the grids were transferred onto a droplet of the streptavidin-gold complex and incubated in a humidity chamber at room temperature for $60 \mathrm{~min}$. Following 5 washing steps with $50 \mathrm{mM}$ Tris, the sections were postfixed in $1 \%$ glutaraldehyde for $10 \mathrm{~min}$ and again washed thoroughly with aqua bidestillata. Subsequently, the grids were quickly dried with filter paper and incubated on drops of silver enhancement solution, following manufacturer's instructions, for $3 \mathrm{~min}$. After several rinses with aqua bidestillata, the grids were air-dried, stained with uranyl acetate and lead citrate using a Reichert ultrastainer, and observed with a Zeiss EM 902 transmission electron microscope.

We ran 2 types of controls alongside the incubations: (1) The specificity of the lectin binding was checked by competitive inhibition with D-mannose (SIGMA), dissolved in the same buffer. The NPA-biotin conjugate and a man- nose solution $(0.6 \mathrm{M})$ were mixed 1:1 (resulting sugar concentration of $0.3 \mathrm{M}$ ) and incubated on a rocking table at room temperature for $10 \mathrm{~min}$. The grids were then incubated in this lectin-sugar solution parallel to the pure lectin solution. This and the following steps were carried out as described above. (2) To screen for the presence of endogenous biotin, the sections were incubated as described above, omitting the lectin incubation step.

Statistical analyses. Scheffé's test for pairwise multiple comparison was used to test for significant differences between the sugar treatments and the control treatment. Sugar treatments and the control were used as grouping factor. The following equation was used to explain the percentage of aposymbiotic worms $(y)$ by the incubation time $(x): y=a \times[1-\exp (-b \times x)]$. Regressions were calculated with the whole data set. The effects of the different sugar concentrations were tested by Kruskal-Wallis 1-way analysis of variance using the concentrations as grouping variable. Analyses were carried out with SPSS 10.0, and Sigma Plot 2000 (SPSS).

\section{RESULTS}

\section{In vivo sugar incubations}

Detachment of symbionts occurred during incubation of living worms in different monosaccharide solutions as well as in seawater in all tested species, although to a different extent.

The detachment rate (determined as percentage of aposymbiotic [bacteria-free] worms after $90 \mathrm{~h}$ incubation) of the control was not significantly different from the tested sugar solutions in Eubostrichus topiarius, E.

Table 2. Laxus cosmopolitus and L. oneistus. Results of Scheffé's test for pairwise multiple comparison of percentage of aposymbiotic specimens after incubation in different solutions for $90 \mathrm{~h}$ given as p-values. D-mannose and L-rhamnose treatments differed significantly from all other treatments and from the control for both species. No significant differences (ns) were found between D-mannose and L-rhamnose treatment ( $\mathrm{p}=0.995$ for L. Cosmopolitus; $\mathrm{p}=0.986$ for $L$. oneistus). nt: not tested

\begin{tabular}{|lcccc|} 
& \multicolumn{2}{c}{ L. cosmopolitus } & \multicolumn{2}{c|}{ L. oneistus } \\
& Mannose & Rhamnose & Mannose & Rhamnose \\
\hline Mannose & - & $\mathrm{ns}$ & - & $\mathrm{ns}$ \\
Rhamnose & $\mathrm{ns}$ & - & $\mathrm{ns}$ & - \\
Fucose & $<0.001$ & $<0.001$ & 0.001 & 0.011 \\
Glucose & $<0.001$ & $<0.001$ & 0.001 & 0.014 \\
Galactose & $<0.001$ & $<0.001$ & 0.003 & 0.028 \\
N-acetyl-galactosamine & $<0.001$ & $<0.001$ & $<0.001$ & 0.001 \\
N-acetyl-glucosamine & $\mathrm{nt}$ & $\mathrm{nt}$ & $<0.001$ & 0.004 \\
Control & $<0.001$ & $<0.001$ & $<0.001$ & $<0.001$ \\
& & & & \\
\hline
\end{tabular}


dianae and Stilbonema maium (data not shown).

In contrast, in Laxus cosmopolitus and $L$. oneistus, the detachment rate was significantly higher after incubation in D-mannose and L-rhamnose compared to that in all other sugars and the control (Fig. 1). No significant differences of detachment rate were found between D-mannose and L-rhamnose treatments in either species (Fig.1). We tested the percentages after $90 \mathrm{~h}$ incubation with Scheffé's test (p-values, Table 2). Differences in bacterial detachment rates due to the sugar concentrations used were tested for both treatments (D-mannose, L-rhamnose) and for both species (Laxus cosmopolitus, L. oneistus) and revealed no significant difference (p-values: 0.371 to 0.683 , Kruskal-Wallis 1-way analysis of variance). Therefore we pooled the incubation samples for the $0.1,0.3,0.5$, and $0.7 \mathrm{M}$ D-mannose solutions and the samples for the 0.1 and $0.5 \mathrm{M}$ L-rhamnose solutions, respectively.

Detachment of symbionts was not observed until after $16 \mathrm{~h}$ incubation. In both species, with both sugars, the percentage of aposymbiotic worms increased significantly with increasing incubation time; the time course (mean $\pm \mathrm{SD}$ ) of incubation in $\mathrm{D}$ mannose, L-rhamnose and the control is shown in Fig. 2. Exponential regressions were fitted to mannose $\left(\mathrm{R}^{2}=0.55, \mathrm{p}<\right.$ $0.0001)$ and rhamnose $\left(\mathrm{R}^{2}=0.80, \mathrm{p}<0.0001\right)$ values in Laxus cosmopolitus and to mannose $\left(\mathrm{R}^{2}=0.61, \mathrm{p}<0.0001\right)$ and rhamnose $\left(\mathrm{R}^{2}=0.35, \mathrm{p}=0.0005\right)$ values in L. oneistus. The linear regressions of the control values were significant in L. cosmopolitus $\left(\mathrm{R}^{2}=\right.$ 0.43, $\mathrm{p}<0.0001)$, but not in $L$. oneistus $\left(\mathrm{R}^{2}=\right.$ $0.11, \mathrm{p}=0.059)$. However, the mean values for detachment of symbionts during the incubation in the control did not exceed $29 \%$ in either species (Fig. 2).

The survival rate of the worms was calculated as the percentage of total incubated individuals of each species per treatment after $90 \mathrm{~h}$ incubation (Table 1). For Laxus cosmopolitus and L. oneistus the rates were generally high in all simple 6 carbon sugar solutions with the exception of the $0.7 \mathrm{M}$ mannose solution, but low in the N-acetyl sugars. Eubostrichus topiarius and $E$. dianae reacted similarly, with lower survival rates in the $\mathrm{N}$-acetyl sugars compared to the other sugars. Stilbonema maium showed generally very low survival rates, with the exception of the fucose incubation.
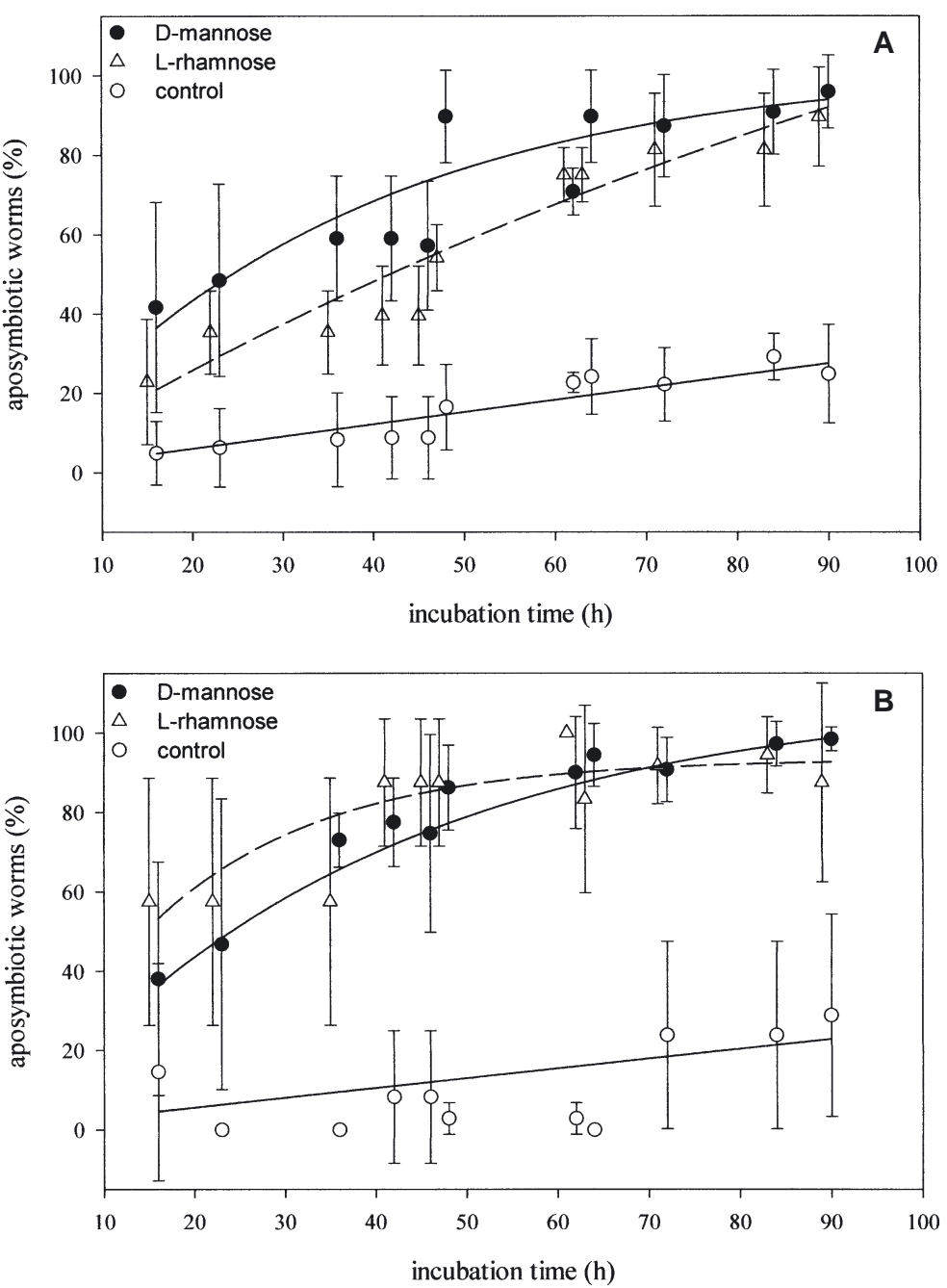

Fig. 2. (A) Laxus cosmopolitus and (B) L. oneistus. Mean $( \pm \mathrm{SD})$ percentage of aposymbiotic worms during in vivo incubation with D-mannose (exponential regression, solid line), L-rhamnose (exponential regression, dashed line) and control incubations in artificial seawater (linear regression, solid line). (A) L. cosmopolitus: $\mathrm{D}-$ mannose ( $\mathrm{n}=2$ to 11 , subsample: mean $=4.3)$, L-rhamnose $(\mathrm{n}=4$, subsample: mean $=4.3)$, control $(\mathrm{n}=2$ to 9 , subsample: mean $=6.4)$; $(\mathrm{B}) L$. oneistus: $\mathrm{D}$-mannose $(\mathrm{n}=2$ to 8 , subsample: mean $=13.5)$, L-rhamnose $(\mathrm{n}=2$ to 4 , subsample: mean $=4.8)$, control $(\mathrm{n}=2$ to 8 , subsample: mean $=8.3)$

Symbionts, whether detached or not, survived all sugar and control incubations for at least $90 \mathrm{~h}$ (data not shown). Although we used filtered seawater to prepare the solutions and sealed the staining blocks during incubation, minor contamination with putative heterotrophic bacteria could not be prevented. However, screening of the detached bacteria and the still attached symbionts with a biochemical viability test resulted in green staining only (color for live bacteria) for all filtered bacteria. Since it was only important to test whether the symbionts were alive after detachment, it was not relevant to distinguish between 


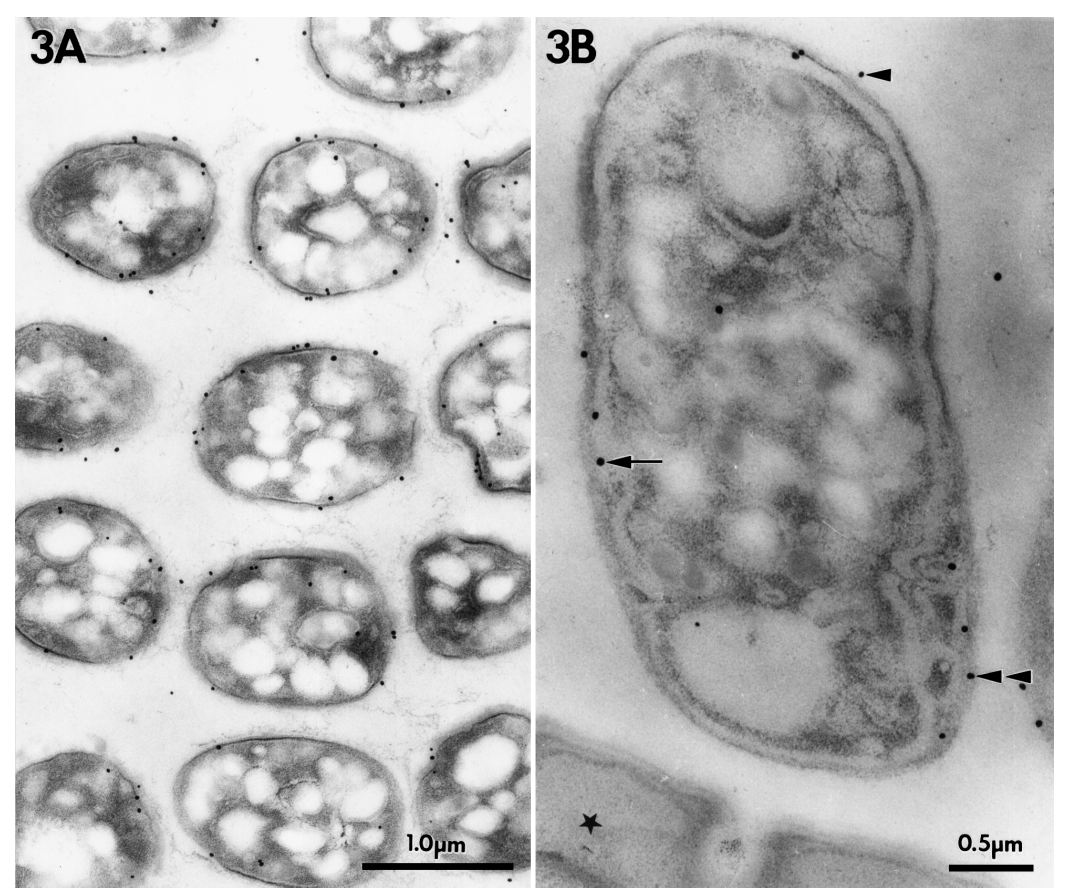

Fig. 3. Laxus cosmopolitus. In vitro incubation with gold-labeled Narcissus pseudonarcissus agglutinin (specificity: $\alpha$-D-mannose) on ultrathin sections. (A) Cross-section of symbionts; (B) detail of symbionts in longitudinal section; asterisk: cuticle of host; arrow: periplasmic space; single arrowhead: extracellular matrix of symbiont; double arrowhead: outer membrane of symbiont

\section{DISCUSSION}

A central question for all symbiotic associations depending on environmental transmission of the symbionts addresses the mechanism of symbiont recognition by the host. De novo infection of each host generation is known from many well-studied cases, including a variety of nitrogen-fixing, bioluminescent, and algal-invertebrate symbioses (Trench 1993, van Rhijn \& Vanderleyden 1995, Hirsch 1999, McFall-Ngai \& Ruby 2000, Nyholm et al. 2000). The stilbonematins not only have to acquire their respective symbionts after hatching, but additionally 4 times after each molt. A reliable mechanism for the recognition of a specific bacterial phylotype amongst the diversity of bacteria in the interstitial marine environment is vital for perpetuity.

Since D-mannose and L-rhamnose caused significantly higher detachment rates of the symbionts in Laxus cosmopolitus and $L$. oneistus than incubations with seawater and with all other tested sugars, we assume that

symbionts and heterotrophs; in addition one can easily recognize the symbionts as they are on average bigger than most known marine heterotrophic bacteria.

\section{In vivo incubation with FITC-labeled lectins}

D-mannose/D-glucose and N-acetyl-D-glucosamine was detected on the symbionts of Laxus cosmopolitus but not on the host's cuticle. Only secretions of the amphid and of the glandular sensory organs, structures known to secrete mucopolysaccharides (Nebelsick et al. 1992, Bauer-Nebelsick et al. 1995) were labeled. D-galactose and N-acetyl-D-galactosamine were found neither on the bacteria nor on the cuticle of $L$. cosmopolitus.

\section{Post-embedding lectin ultracytochemistry}

Incubation with NPA on ultrathin sections of Laxus cosmopolitus revealed strong labelling of the bacteria, no labelling of the worm's cuticle and virtually no background labelling. The label was seen very specifically in the periplasmic space, the outer membrane and the ECM of the symbionts (Fig. 3). Both controls were negative. these sugars play a decisive role in the attachment mechanism between host and symbiont. The time course of detachment suggests a slow diffusion rate of the sugars through the mucus matrix in which the bacteria are embedded and/or a slow disintegration of the mucus-bound bacterial coat.

None of the sugar solutions or the seawater control induced significant detachment of the bacterial consortium in Eubostrichus topiarius, E. dianae or Stilbonema maium. It is possible that attachment in these species is mediated through sugars other than those tested, or eventually simultaneous incubation with more than one sugar could induce detachment of the multilayered bacterial coverage. However, this study revealed no information on the binding mechanism in these species.

Since lectin tests found D-mannose to be present only in the bacterial membrane and not in the host's cuticle, the search for the opposite binding molecule, most probable a lectin, should concentrate on the latter. It was not possibly to test for the presence of L-rhamnose in the symbionts, as no rhamnose-specific lectin was commercially available at the time of the study.

Specificity in carbohydrate-lectin interactions is achieved in many different ways (see Drickamer \& Taylor 1993, Weis \& Drickamer 1996, Brooks et al. 1997). For example, lectins specifically recognize cer- 
tain combinations of monomers within oligosaccharides, or specificity is achieved through different orientation of the same monomers (i.e. $\alpha 1-6$ linked mannose vs $\alpha 1-3$ linked mannose) ( $\mathrm{Ng}$ et al. 2002).

Zamze et al. (2002) found that the macrophage mannose receptor $\left(\mathrm{Ca}^{2+}\right.$-dependent lectin) bound with the highest affinity to D-mannose, but also to L-rhamnose although with a lower affinity. However, the detachment rates of symbionts during our incubations showed no significant difference between L-mannose and L-rhamnose. This points to an involvement in the binding mechanism of both sugars in any combination as an oligosaccharide. Alternatively, it is possible that only 1 of these 2 sugars actually mediates the binding. In such case, L-rhamnose would have competed with D-mannose bound to a mannose-specific lectin or, vice versa, D-mannose would have caused detachment by competing with L-rhamnose bound to a rhamnosespecific lectin. Theoretically this would be possible, since the specificity of C-type animal lectins is a series of cooperative hydrogen bonds involving Hydroxyl Groups 3 and 4 combined with coordination to a calcium ion. L-rhamnose is a 6-deoxy mannose and differs only in the substitute on the C6 position (Drickamer 1997, $\mathrm{Ng}$ et al. 2002, Zamze et al. 2002). At this point, we cannot say which of these 2 possibilities is true for the Laxus sp. Isolation and characterization of the presumed lectins from the worms will reveal more details on the binding mechanism.

Acknowledgements. A.N. would like to thank H. SchenkelBrunner, Vienna Bio Center, for introducing her to glycobiology and for providing several sugars for the experiments, and Katrina Vanura and Thomas Buchholz for their help with animal samplings. We would like to thank 3 anonymous reviewers for their valuable criticism. This study was supported by the Austrian Science Foundation (FWF projects P-11388-Bio and P-15413-Bio, Jörg Ott, principal investigator) and the Caribbean Coral Reef Ecosystems (CCRE) Program of the Smithsonian National Museum of Natural History (Washington, DC). This is contribution no. 672 of the (CCRE) Program.

\section{LITERATURE CITED}

Arason GJ (1996) Lectins as defence molecules in vertebrates and invertebrates. Fish Shellfish Immunol 6:277-289

Bauer-Nebelsick M, Blumer M, Urbancik W, Ott JA (1995) The glandular sensory organ of Desmodoridae (Nematoda)-ultrastructure and phylogenetic implications. Invertebr Biol 114:211-219

Bauer-Nebelsick M, Bardele CF, Ott JA (1996a) Redescription of Zoothamnium niveum (Hemprich \& Ehrenberg, 1831) Ehrenberg 1838 (Oligohymenophora, Peritrichida), a ciliate with ectosymbiotic, chemoautotrophic bacteria. Eur J Protistol 32:18-30

Bauer-Nebelsick M, Bardele CF, Ott JA (1996b) Electron microscopic studies on Zoothamnium niveum (Hemprich \& Ehrenberg, 1831) Ehrenberg 1838 (Oligohymenophora, Peritrichida), a ciliate with ectosymbiotic, chemoauto- trophic bacteria. Europ J Protistol 32:202-215

Beuth J, Uhlenbruck G (1995) Adhesive properties of bacteria. In: Richardson PD, Steiner M (eds) Principles of cell adhesion. CRC Press, Boca Raton, FL, p 87-105

Bird AF, Zuckermann BM (1989) Studies on the surface coat (glycocalyx) of the dauer larva of Anguina agrostis. Int J Parasitol 19:235-240

Bird AF, Bonig I, Bacic A (1989) Factors affecting the adhesion of micro-organisms to the surfaces of plant-parasitic nematodes. Parasitology 98:155-164

Blaxter ML, Page AP, Rudin W, Maizels RM (1992) Nematode surface coats: actively evading immunity. Parasitol Today $8: 243-247$

Brandley BK (1991) Cell surface carbohydrates in cell adhesion. Semin Cell Biol 2:281-287

Brooks SA, Leathem AJC, Schumacher U (1997) Lectin histochemistry. BIOS Scientific Publishers, Oxford

Cary SC, Stein JL (1998) Spanning the thermal limits: an extreme eurythermal symbiosis. Cah Biol Mar 39:275-278

Costerton JW, Geesey GG, Cheng KJ (1978) How bacteria stick. Sci Am 238:86-95

Decho AW (1990) Microbial exopolymer secretions in ocean environments: their role(s) in food webs and marine processes. Oceanogr Mar Biol Annu Rev 28:73-153

Diaz CL, Logman T, Stam HC, Kijne JW (1995) Sugar-binding activity of pea lectin expressed in white clover hairy roots. Plant Physiol 109:1167-1177

Drickamer K (1997) Making a fitting choice: common aspects of sugar-binding sites in plant and animal lectins. Structure 5:465-468

Drickamer K, Taylor ME (1993) Biology of animal lectins. Annu Rev Cell Biol 9:237-264

Ewart KV, Johnson SC, Ross NW (1999) Identification of a pathogen-binding lectin in salmon serum. Comp Biochem Physiol Part C 123:9-15

Fenchel T, Finley BJ (1989) Kentrophoros: a mouthless ciliate with a symbiotic kitchen garden. Ophelia 30:75-93

Fraysse N, Couderc F, Poinsot V (2003) Surface polysaccharide involvement in establishing the rhizobium-legume symbiosis. Eur J Biochem 270:1365-1380

Herken R, Manshausen B (1998) Electron microscopy: use of lectin-gold after embedding. In: Rhodes JM, Milton JD (eds) Lectin methods and protocols. Humana Press, Totowa, NJ, p 111-119

Hirabayashi J, Satoh M, Ohyama Y, Kasai K (1992) Purification and characterization of $\beta$-galactoside-binding proteins from Caenorhabditis elegans. J Biochem 111: $553-555$

Hirsch AM (1999) Role of lectins (and rhizobial exopolysaccharides) in legume nodulation. Curr Opin Plant Biol 2: 320-326

Kaku H, Van Damme EJ, Peumans WJ, Goldstein IJ (1990) Carbohydrate-binding specificity of the daffodil (Narcissus pseudonarcissus) and amaryllis (Hippeastrum hybr.) bulb lectins. Arch Biochem Biophys 279(2):298-304

Kijne JW, Smit G, Diaz CL, Lugtenberg BJ (1988) Lectinenhanced accumulation of manganese-limited Rhizobium leguminosarum cells on pea root hair tips. J Bacteriol 170: 2994-3000

Maizels RM, Baxter ML, Selkirk ME (1993) Forms and functions of nematode surfaces. Exp Parasitol 77:380-384

McFall-Ngai MJ (1994) Animal-bacterial interactions in the early life history of marine invertebrates: the Euprymna scolopes/Vibrio fischeri symbiosis. Am Zool 34:554-561

McFall-Ngai MJ, Ruby EG (2000) Developmental biology in marine invertebrate symbioses. Curr Opin Microbiol 3(6): 603-607 
Nebelsick M, Blumer M, Novak R, Ott J (1992) A new glandular sensory organ in Catanema sp. (Nematoda, Stilbonematinae). Zoomorphology 112:17-26

Ng KKS, Kolatkar AR, Park-Snyder S, Feinberg H, Clark DA, Drickamer K, Weis WI (2002) Orientation of bound ligands in mannose-binding proteins: implications for multivalent ligand recognition. J Biol Chem 277:16088-16095

Nyholm SV, Stabb EV, Ruby EG, McFall-Ngai MJ (2000) From the cover: establishment of an animal-bacterial association: recruiting symbiotic vibrios from the environment. Proc Natl Acad Sci 97:10231-10235

Oeschger R, Schmaljohann R (1988) Association of various types of epibacteria with Halicryptus spinulosus (Priapulida). Mar Ecol Prog Ser 48:285-293

Ott JA (1996) Sulphide ectosymbioses in shallow marine habitats. Biosyst Ecol Ser 11:369-382

Ott JA, Novak R (1989) Living at an interface: meiofauna at the oxygen/sulfide boundary of marine sediments. In: Ryland JS, Tyler PA (eds) Reproduction, genetics and distributions of marine organisms. Olsen \& Olsen, Fredensborg, p 415-422

Ott JA, Novak R, Schiemer F, Hentschel U, Nebelsick M, Polz $M$ (1991) Tackling the sulfide gradient: a novel strategy involving marine nematodes and chemoautotrophic ectosymbionts. PSZN I: Mar Ecol 12:261-279

Ott JA, Bright M, Schiemer F (1998) The ecology of a novel symbiosis between a marine peritrich ciliate and chemoautotrophic bacteria. PSZN I: Mar Ecol 19:229-243

Page AP, Rudin W, Fluri E, Blaxter ML, Maizels RM (1992) Toxocara canis: a labile antigenic coat overlying the epicuticle of infective larvae. Exp Parasitol 75:72-86

Polz MF, Cavanaugh CM (1995) Dominance of one phylotype at a Mid-Atlantic Ridge hydrothermal vent site. Proc Natl Acad Sci USA 92:7232-7236

Polz MF, Felbeck H, Novak R, Nebelsick M, Ott JA (1992) Chemoautotrophic, sulfur-oxidizing symbiotic bacteria on marine nematodes: morphological and biochemical characterization. Microb Ecol 24:313-319

Polz MF, Distel DL, Zarda B, Amann R, Felbeck H, Ott JA, Cavanaugh CM (1994) Phylogenetic analysis of a highly specific association between ectosymbiotic, sulfuroxidizing bacteria and a marine nematode. Appl Environ Microbiol 60:4461-4467

Polz MF, Harbison C, Cavanaugh CM (1999) Diversity and

Editorial responsibility: David Caron,

Los Angeles, California, USA heterogeneity of epibiotic bacterial communities on the marine nematode Eubostrichus dianae. Appl Environ Microbiol 65:4271-4275

Polz MF, Ott JA, Bright M, Cavanaugh CM (2000) When bacteria hitch a ride. Am Malacol Soc News 66:531-539

Price NP (1999) Carbohydrate determinants of Rhizobium-legume symbioses. Carbohydr Res 317:1-9

Roth J (1978) The lectins-molecular probes in cell biology and membrane research. Exp Pathol 3:1-86

Sharon N, Lis H (1993) Carbohydrates in cell recognition. Sci Am 268:82-89

Spiegel Y, Cohn E, Spiegel S (1982) Characterization of sialyl and galactosyl residues on the body wall of different plant-parasitic nematodes. J Nematol 14:33-39

Sutherland IW (1977) Bacterial exopolysaccharides-their nature and production. In: Sutherland IW (ed) Surface carbohydrates of the procaryote cell. Academic Press, New York, p 27-96

Trench RK (1993) Microalgal-invertebrate symbioses: a review. Endocytobiosis Cell Res 9:135-175

van Rhijn P, Vanderleyden J (1995) The Rhizobium-plant symbiosis. Microbiol. Rev. 59:124-142

van Rhijn P, Goldberg RB, Hirsch AM (1998) Lotus corniculatus nodulation specificity is changed by the presence of a soybean lectin gene. Plant Cell 10:1233-1250

Venkataraman C, Haack BJ, Bondada S, Kwaik YA (1997) Identification of a Gal/GalNAc lectin in the protozoan Hartmannella vermiformis as a potential receptor for attachment and invasion by the legionnaires' disease bacterium. J Exp Med 186:537-547

Wang XH, Leung KY (2000) Biochemical characterization of different types of adherence of Vibrio species to fish epithelial cells. Microbiology (Reading) 146:989-998

Weis WI, Drickamer K (1996) Structural basis of lectin-carbohydrate recognition. Annu Rev Biochem 65:441-473

Zamze S, Martinez-Pomares L, Jones H, Taylor PR, Stillion RJ, Gordon S, Wong SYC (2002) Recognition of bacterial capsular polysaccharides and lipopolysaccharides by the macrophage mannose Receptor. J Biol Chem 277: 41613-41623

Zuckerman BM, Kahane I, Himmelhoch S (1979) Caenorhabditis briggsae and C. elegans: partial characterization of cuticle surface carbohydrates. Exp Parasitol $47: 419-424$

Submitted: March 16, 2001; Accepted: November 6, 2003

Proofs received from author(s): February 9, 2004 